\title{
The role of biological agents in the microstructural and mineralogical transformations in aluminium lateritic deposit in Central Brazil
}

\author{
Fábio Soares de Oliveira ${ }^{\mathrm{a}, \mathrm{b}, *}$, Angélica Fortes Drummond Chicarino Varajão ${ }^{\mathrm{b}}$, \\ César Augusto Chicarino Varajão ${ }^{\mathrm{b}}$, Carlos Ernesto Gonçalves Reynaud Schaefer ${ }^{\mathrm{c}}$, Bruno Boulangé ${ }^{\mathrm{d}}$ \\ a Departamento de Geografia, Instituto de Geociências, Universidade Federal de Minas Gerais, UFMG, Av. Antônio Carlos, 6627, Belo Horizonte, 31270-901 MG, Brazil \\ b Departamento de Geologia, Universidade Federal de Ouro Preto, UFOP, Campus Morro do Cruzeiro, s/n, Ouro Preto, 35400-000 MG, Brazil \\ c Departamento de Solos, Universidade Federal de Viçosa, UFV, Av. Ph Rolfs, s/n, Viçosa, 36700-000 MG, Brazil \\ ' Museé de la Bauxite, Tourves, France
}

\section{A R T I C L E I N F O}

Article history:

Received 9 October 2012

Received in revised form 17 February 2014

Accepted 23 February 2014

Available online 15 March 2014

\section{Keywords:}

Bauxite

Biological activity

Microstructural transformations

Mineralogical transformations

Barro Alto

\begin{abstract}
A B S T R A C T
Petrological studies using X-ray diffraction (XRD) and micromorphological analyses (Optical Microscopy and SEM), were done to understand the role of biological activity in the evolution of Barro Alto bauxite. The results indicated that this influence came through structural (or microstructural) and mineralogical transformations, namely: I - the bioturbation caused by termites and II - the mechanical degradation and geochemical transformation promoted by roots. In the bioturbation caused by termites were formed: I - a intergrain micro-aggregate structure, characterised by gibbsite crystals from isalteritic bauxite fragmentation on the bottom of the profile and II - a granular structure characterised by a termitic microaggregates with fragments of gibbsite immersed in a kaolinite-gibbsite-goethite-boehmite micromass, formed by bioturbation of the degradation clay with nodules of gibbsite, whose origin is the geochemistry degradation of isalteritic bauxite. The processes associated with geochemical and mechanical degradation caused by roots were responsible for the genesis of: I - a porphyric texture with bauxite fragments surrounded by nonaggregate material and II - fine monic structure where the gibbsite neoformation has the mould cavities left by old roots, generating riziform features.
\end{abstract}

(c) 2014 Elsevier B.V. All rights reserved.

\section{Introduction}

Since the beginning of soil science (Dokuchaev, 1893 and Branner, 1896, cited in Espindola, 2008) and in studies predating formal soil science (Darwin, 1881), biological agents have been known to be factors actively involved in most pedological processes. Many soil attributes, especially those related to structure and chemical and mineralogical composition, are formed or transformed via biota (Ugolini and Edmonds, 1983).

Influences exerted on soil attributes by biological activity include the following: the origin and stability of aggregates (Fregonezi et al., 2001; Harris et al., 1966; Martin, 1945, 1946; Tisdal and Oades, 1982); the origin of granular structures associated with termites in tropical soils (Black and Okwakol, 1997; Dangerfield et al., 1998; Eschenbrenner, 1986; Garnier-Sillan et al., 1985; Jungerius et al., 1999; Kooyman and Onk, 1987; Lavelle et al., 1992; Lee and Wood, 1971; Reatto et al.,

\footnotetext{
* Corresponding author at: Departamento de Geografia, Instituto de Geociências, Universidade Federal de Minas Gerais, UFMG, Av. Antônio Carlos, 6627, Belo Horizonte, 31270-901 MG, Brazil. Tel.: + 5531 75151177; fax: + 553135591606.

E-mail address: fabiosolos@gmail.com (F.S. de Oliveira).
}

2009; Schaefer, 2001); alterations in the soil chemical composition, nutrient availability, and physico and chemical properties (Black and Okwakol, 1997; Holt et al., 1998; Lal, 1988; Sarcinelli et al., 2009); changes in porosity and hydro-physical conditions (Lavelle and Pashanasi, 1989; Lee and Foster, 1991; Leonard and Rajot, 2001; Mando and Stroosnijder, 1999; Miklós, 1995; Taylor and Brar, 1991); and the deposition of excrement involved in the constitution of soil microstructures (Brewer and Sleeman, 1988; Bullock et al., 1985). Various studies have also reported the influence of the evolution of ferruginous (Beauvais, 2009) or aluminous soil cuirasses (Eggleton and Taylor, 2008; Hao et al., 2010; Laskou and Economou-Eliopoulos, 2007; Schwars, 1996), thereby emphasising the involvement of organisms in rock weathering processes.

The present study hypothesized a marked influence of biological activity for the differentiation of aluminous lateritic areas of the Barro Alto bauxitic massif, highlighting microstructural and mineralogical transformations involved in this activity. The Barro Alto bauxitic massif is a bauxite deposit with an exploitable reserve of approximately 160 million tons and is located in Goias State (GO), Central Brazil (Fig. 1a). The bauxite was formed as a result of the anorthosite alteration (Oliveira et al., 2011) of the upper series of the Barro Alto Stratiform Mafic-Ultramafic Complex (CBA) in the Tocantins Province (Almeida et al., 1981). The 


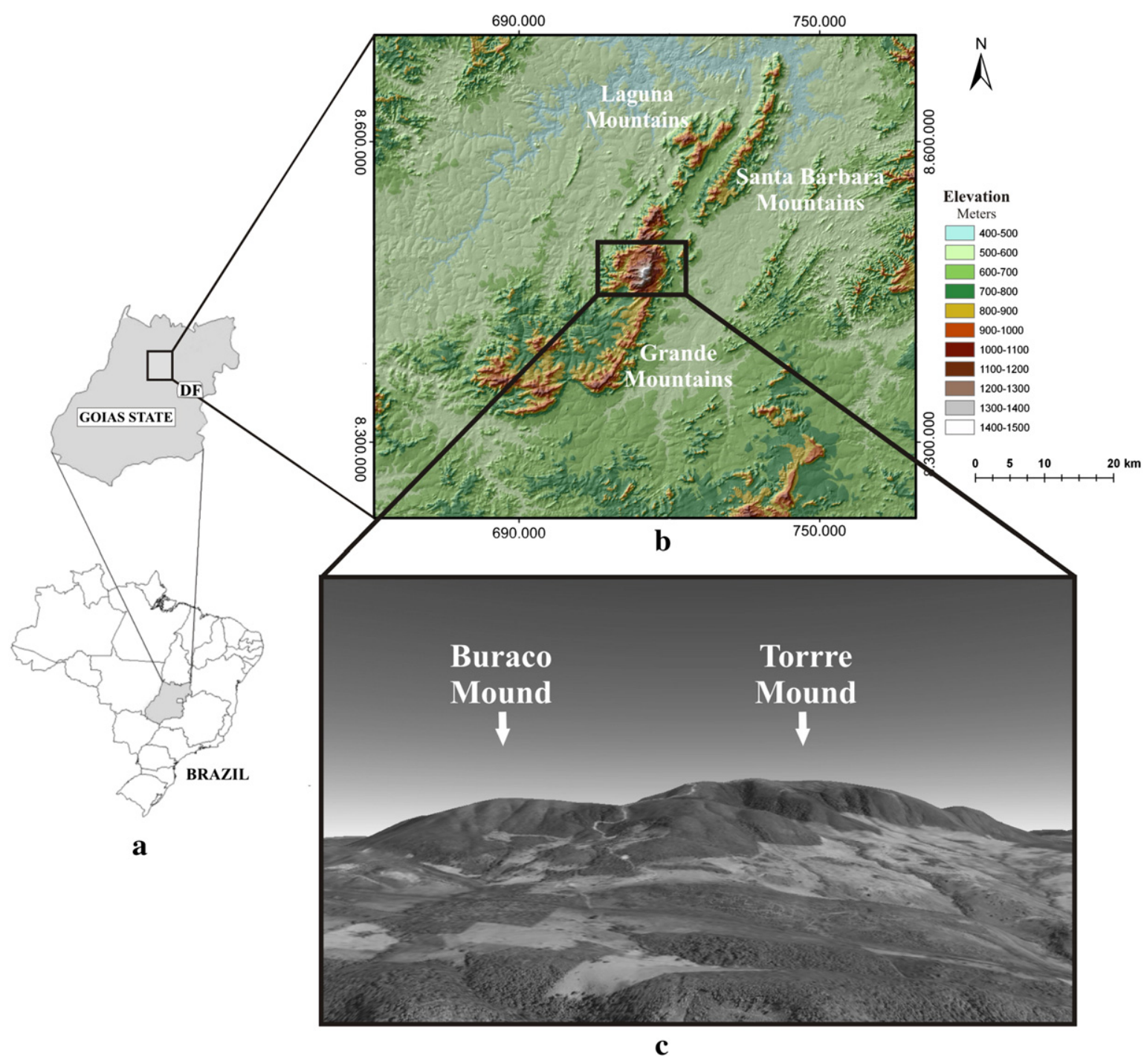

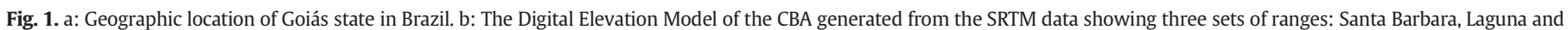
Grande and bauxitic massif of Barro Alto. c: Image from Google Earth (with $2 \times$ vertical zoom) showing the Torre and Buraco Hills.

results of the present study will contribute to the understanding of the role of biological activity in the polygenetic evolution of lateritic mantles, contributing to the geoecological characterisation of deeply and extensively weathered areas.

\section{Materials and methods}

The regional landform of the Barro Alto bauxitic massif is characterised by three mountain ranges: Santa Barbara, Laguna and Grande (Fig. 1b). The studied massif is located in Serra Grande, which is divided into two hills; named Morro da Torre and Morro do Buraco (Fig. 1c). These two hills have altitudes of 1500 and $1300 \mathrm{~m}$, respectively, and exhibit a prominent and contrasting relief in comparison with the lower surroundings, whose surface spreads between 550 and 900 $m$ in elevation.

The region has a tropical climate with an average annual rainfall of $1600 \mathrm{~mm}$. Cerrado (open Savanna) vegetation is preserved above $1000 \mathrm{~m}$ in elevation (Brasil, Ministério das Minas e Energia, Departamento Nacional da Produção de Minerais, Projeto RADAMBRASIL, 1981), whereas agricultural activity is dominant below this altitude.

In previous studies of the evolution of the Barro Alto bauxitic massif (Oliveira et al., 2013a), some morphological structures were reported to indicate the participation of biological activity in the differentiation of the bauxitic facies. For that purpose, we selected fifteen representative samples of such structures for combined mineralogical and micromorphological analyses.

The selected, undisturbed and oriented samples were impregnated with a polyester resin, and thin sections of $6 \mathrm{~cm}$ by $10 \mathrm{~cm}$ were prepared using standard methods (Benyarku and Stoops, 2005). Micromorphological analyses were performed using a Zeiss Axiophot trinocular optical microscope with an integrated digital camera. Micromorphological descriptions were made using the concepts and terms proposed by Bullock et al (1985) and Stoops (2003). The limit between coarse and fine material was defined in this study as $2 \mu \mathrm{m}\left(\mathrm{c} / \mathrm{f}_{2} \mu \mathrm{m}\right)$. These micropedological analyses were complemented using a JEOL JSM5510 scanning electron microscope (SEM).

The mineralogical analyses were performed using a PANalytical Empyrean diffractometer with $\mathrm{Cu}$ radiation at intervals of $2^{\circ}$ to $70^{\circ} 2 \theta$, a step of 0.02 , and a count of $10 \mathrm{~s}$ per step. The diffractograms were analysed using X'Pert HighScore software and published standards (Brindley and Brown, 1980).

\section{Results}

Field studies associated with the micromorphological and mineralogical analyses showed that biological activity occurs in two 
ways: through direct bioturbation caused by soil-dwelling termites, or as a result of root growth and decay.

\subsection{Direct bioturbation associated with termites}

A representative profile is shown in Fig. 2. The profile is composed of an organic horizon ( $\mathrm{A}-20 \mathrm{~cm}$ depth), a pedoplasmated horizon (B) up to $2 \mathrm{~m}$ depth and a saprolitic horizon (C) observed up to $8.2 \mathrm{~m}$. At the top, in the A-horizon, occurs a slopewash depositional level $( \pm 60 \mathrm{~cm})$ composed of mixed bauxite fragments. According to Oliveira et al. (2013a), these levels are derived from the colluvial deposition from upland areas.

The activity of the termitaria could be observed on the top of profile in termite mound (Fig. 2). The mound-building termites of the neotropical Brazil are extremely varied, and most mounds are occupied by inquilines, and not just those who start the mound building. Moreover, not all are geophagous. There are reports of more than 17 termite

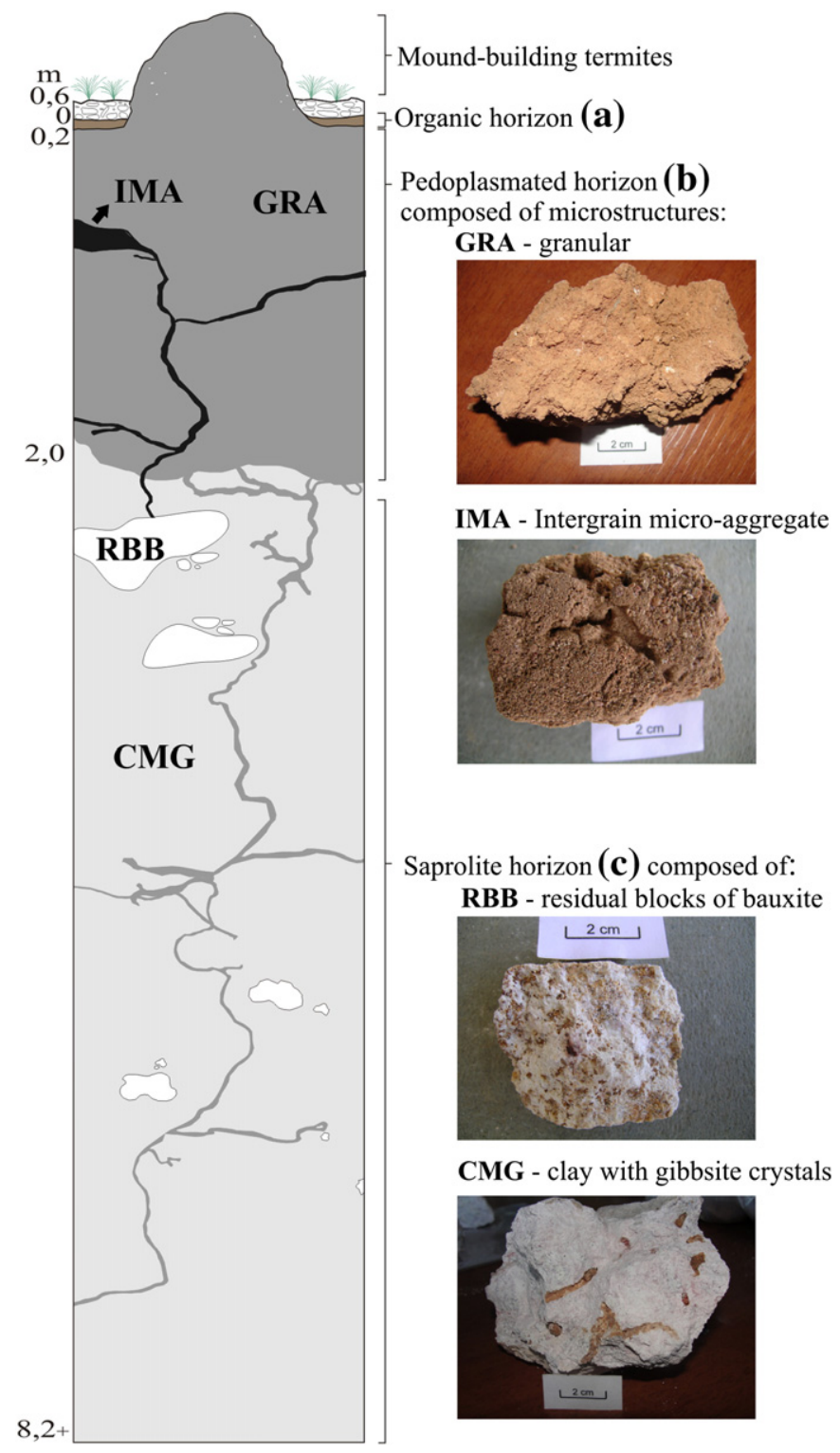

Fig. 2. Soil profile transformed by bioturbation associated with termites. The profile is composed of an organic horizon (a), a pedoplasmated horizon (b) and a saprolitic horizon (c). At the top, in the A-horizon, occurs a slopewash depositional level composed of mixed bauxite fragments. The macroscopic appearance of a termitary highlighting the presence of granular (GRA) and intergrain micro-aggregate (IMA) structures. The saprolite is composed of residual block of bauxite (RBB) and clay with gibbsite crystals (CMG). species in one given mound (Cancello, 1989; DeSouza et al., 2009). We did not identify the termite species, but local observations in this area show a dominance of Nasutitermes sp., as the most common genera.

The microstructures associated with bioturbation caused by termites correspond to the samples indicated by the symbols IMA (Intergrain Micro-Aggregate structure) and GRA (Granular structure) (Fig. 2). Both are located in pedoplasmated horizon. Macro, micromorphological and mineralogical aspects of such microstructures are presented below. Before, we present the materials contained in saprolite aiming to clarify the characteristics of materials that probably served as a source for the bioturbation and pedoplasmation processes. The symbols RBB and CMG indicate, respectively, the "Residual Blocks of Bauxite" and the "Clay Matrix with Gibbsite crystals" (Fig. 2).

\subsubsection{Samples of saprolite}

The CMG in saprolite horizon consists of a whitish to pinkish clay with gibbsite crystals and millimetric fragments $(<2 \mathrm{~mm}$ and $>2 \mu \mathrm{m})$ of pink, isalteritic bauxite (Fig. 2). According to Oliveira et al. (2013b), the genesis of this clay was attributed to the geochemical alteration of massive bauxite by the input of silica-rich solutions, leading to a classical resilicification process. Residual not degraded with isalteritic bauxite boulders can be observed in RBB (Fig. 2). This clay is cut by channels of different sizes which are filled with material, macroscopically, similar to that of GRA (Fig. 2).

Microscopically, the RBB exhibits the same structural organization of the porous massive bauxites described by Oliveira et al. (2011, 2013a). The structure is formed by gibbsite and goethite boxworks (Fig. 3A), generating an isalteritic structure (Nahon, 1991; Delvigne, 1998). The contact between the gibbsite and goethite boxworks is abrupt, with little or no iron dispersed in the matrix. The voids exhibit dimensions ranging from micrometres to centimetres and shapes ranging from rectangular to quadratic. The voids were derived from the consumption of primary minerals (bytownite), which constitutes about $95 \%$ of the fresh rock - anorthosite (Oliveira et al., 2009). In some voids, however unusual, it is possible to observe residual fragments of plagioclase not yet weathered (Fig. 3B). The mineralogy highlights the presence of gibbsite, goethite and anatase in the inner portion of the block (Fig. 4 RBBI) and gibbsite, goethite, kaolinite and anatase in the outer portion (Fig. 4 RBBII). The plagioclase crystals occur insufficiently for their detection in XRD.

CMG exhibits greyish-brown kaolinitic micromass with a speckled b-fabric and locally shows the remains of boxwork structures or linear features, indicating iron dispersion. Near RBB, it is possible to observe more gibbsite nodules, with many destroyed boxworks (Fig. 3C). Away from the blocks, the nodules are rare, and, when they do occur, they appear to be formed of small crystals of gibbsite with irregular borders (Fig. 3D), dispersed in a kaolinitic micromass. The remains of gibbsite and goethite boxworks and the dispersed gibbsite crystals are the coarse material of the groundmass. The voids are also uncommon, isolated, and have a morphology that includes vughs. In the infilled channels have a brownish-yellow colour and a micro-aggregated pattern (Fig. 3E). The mineralogy of the infilling is composed by kaolinite, gibbsite, goethite, anatase and boehmite (Fig. 4 CMGI). The clay surrounding the channels is composed of gibbsite, kaolinite, goethite and anatase (Fig. 4 CMGII).

\subsubsection{Samples of pedoplasmated horizon}

At the macromorphological scale, the IMA (Fig. 2) is characterised by the presence of minute and equidimensional bauxite fragments $(>2 \mu \mathrm{m})$ ranging from pink to whitish in colour (5YR8/3). The fragments are combined with a less abundant yellowish-red clay matrix (5YR5/6) forming a small micro-aggregate already in macroscopic scale. The GRA (Fig. 2) is also characterised by the presence of bauxite fragments; however, these fragments are smaller $(<0.5 \mathrm{~mm})$ and whitish in colour. Such fragments are thoroughly dispersed in a yellowish-red clay matrix 


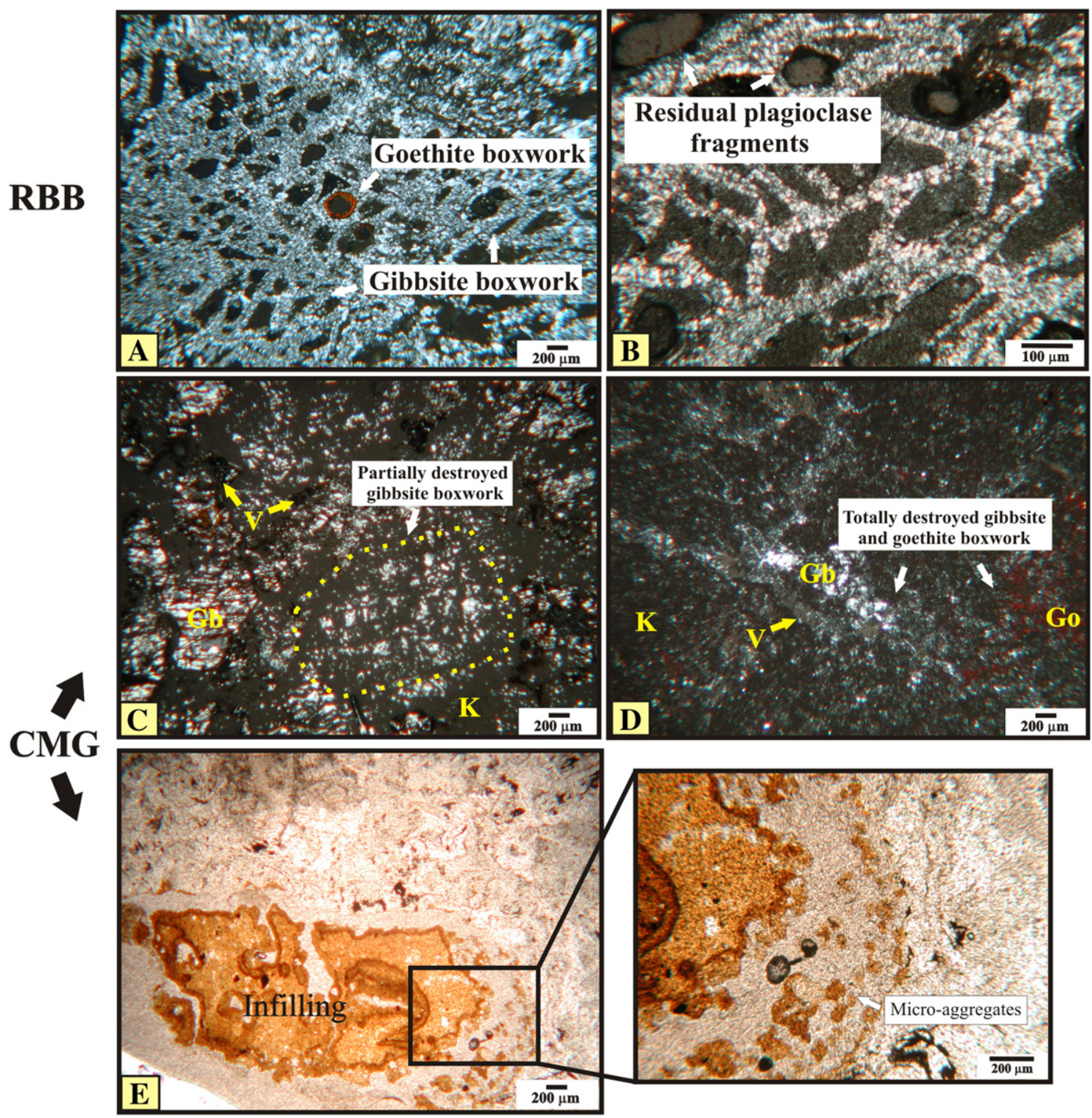

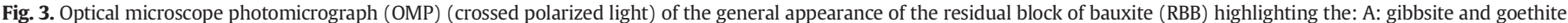

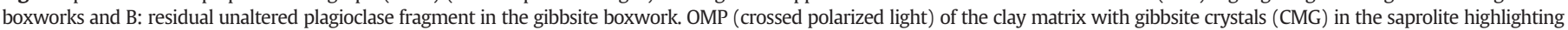

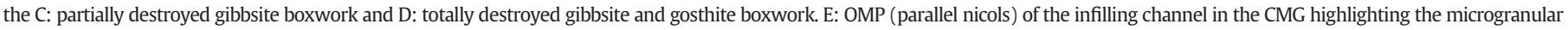
infilling. $\mathrm{Gb}=$ gibbsite; $\mathrm{Go}=$ goethite; $\mathrm{K}=$ kaolinite and $\mathrm{V}=$ void.

(5YR5/2). The matrix in GRA is more abundant than that in IMA and it is composed of sub-rounded to rounded granules, displaying a typical granular structure (Bullock et al., 1985). Both parts have portions with a brittle consistency. In GRA, it is possible to observe abundant biological channels, some of which are hollow, with no visible infilling.

Based on the micromorphological description, IMA and GRA exhibit significant micromorphological differences. In IMA, the fragments represent the coarse material $\left(\mathrm{c} / \mathrm{f}_{2} \mu \mathrm{m}\right)$ and vary from angular to subrounded shapes. They occur isolated (single grains) in larger size and composing the groundmass of micro-aggregates (Fig. 5A and B). Mineralogically, they are composed by gibbsite crystals and ferruginous zones suggesting a origin in broken, dismantled former goethite boxworks, resulting from termite activity (Fig. 5C). Unaltered plagioclase crystals inherited from the RBB below in the saprolite can also be identified floating between fragments (Fig. 5D), confirming that the material was mixed by bioturbation. The distribution and size of the fragments are fairly uniform, suggesting selection of finer particles and resulting in homogenization, promoted by termite activity (pedoturbation process). The micromass of the granular microaggregates has an undifferentiated b-fabric, and a yellowish micromass with a speckled limpidity, pointing to a material with ferralic properties (ISSS Working Group, 2006), or a soil in the ultimate weathering stage (Schaefer, 2001). Mineralogically, the IMA structure is composed of gibbsite, goethite, anatase and boehmite (Fig. 4) in addition to organic matter. Complex packing voids occur, separating the aggregates of single grains.

The GRA has a moderately developed pedality. Aggregates vary from rounded to subangular (Fig. 6) and are separated by compound packing voids system. The groundmass of the aggregate is formed by a yellowish to brown-yellowish micromass with speckled b-fabric and coarse material composed of gibbsite crystals and destroyed fragments of goethite box-works (Fig. 6C). Mineralogically, GRA consists of kaolinite, gibbsite, goethite, anatase and boehmite (Fig. 4). In places, some microaggregates exhibit a zoning that suggests a centrifugal migration of iron to the aggregate surface (Fig. 6C). Abundant channel infilling is present. The cross- (Fig. 6A) and longitudinal sections (Fig. 6B) of channel illustrate their partial infilling by minute 


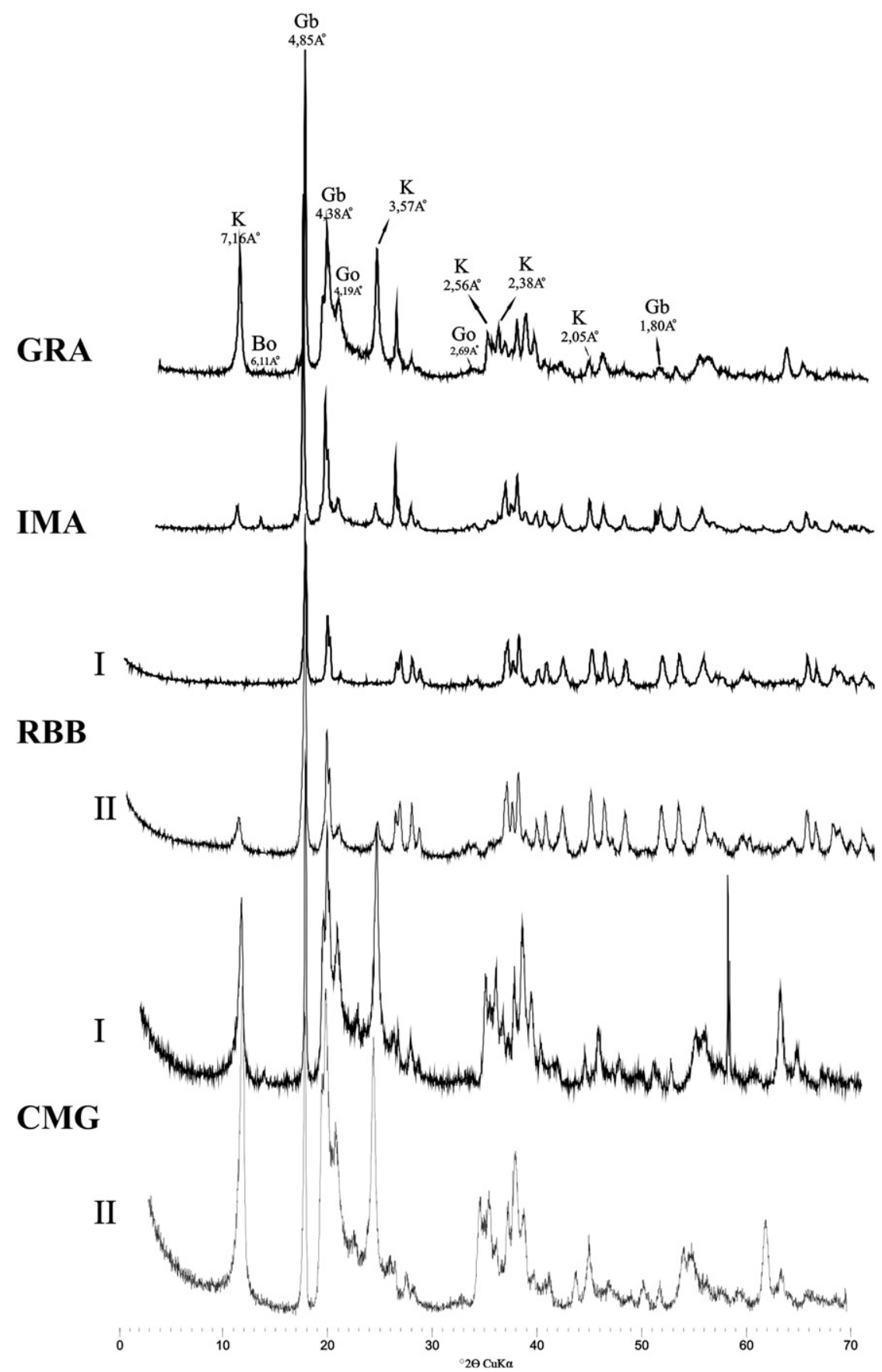

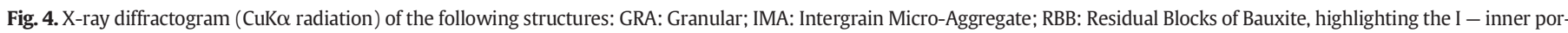

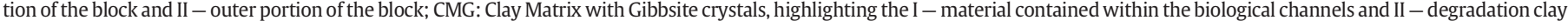
with gibbsite nodules. $\mathrm{Gb}=$ gibbsite; $\mathrm{Bo}=$ boehmite; $\mathrm{Go}=$ goethite; $\mathrm{K}=$ kaolinite.

rounded microaggregates, suggesting a microgranular infilling (Stoops, 2003).

\subsection{Root traces and activity}

Two types of structural pattern associated with root activity were identified: i) a porphyric structure (PFR) and ii) a fine monic structure (FIM).

PFR is present at the top of the profiles throughout most of the upland surface being, therefore recognised as an alteration facies (Oliveira et al., 2009, 2013a). Macromorphologically, this zone contains bauxite fragments surrounded by a brownish (5YR5/6) pedogenetic matrix (Fig. 7A). According to Oliveira et al. (2013a), the fragments have sizes ranging between 0.1 to $10 \mathrm{~cm}$ diameters. The number of fragments decreases from the top to the bottom of the profiles, and they are larger at the bottom. Below this zone, not fragmented massive bauxite occurs.

The micromorphology of the PFR is characterised by dispersed angular bauxite fragments surrounded by a nonaggregated material constituted by clay and gibbsite crystals (Fig. 7B) (Oliveira et al., 2013a). These fragments and gibbsite crystals are larger than $2 \mu \mathrm{m}$ and, therefore, represent the coarse material of the groundmass. In addition, they occur in the groundmass a brown-yellowish micromass with speckled b-fabric and complex packing void system (Bullock et al., 

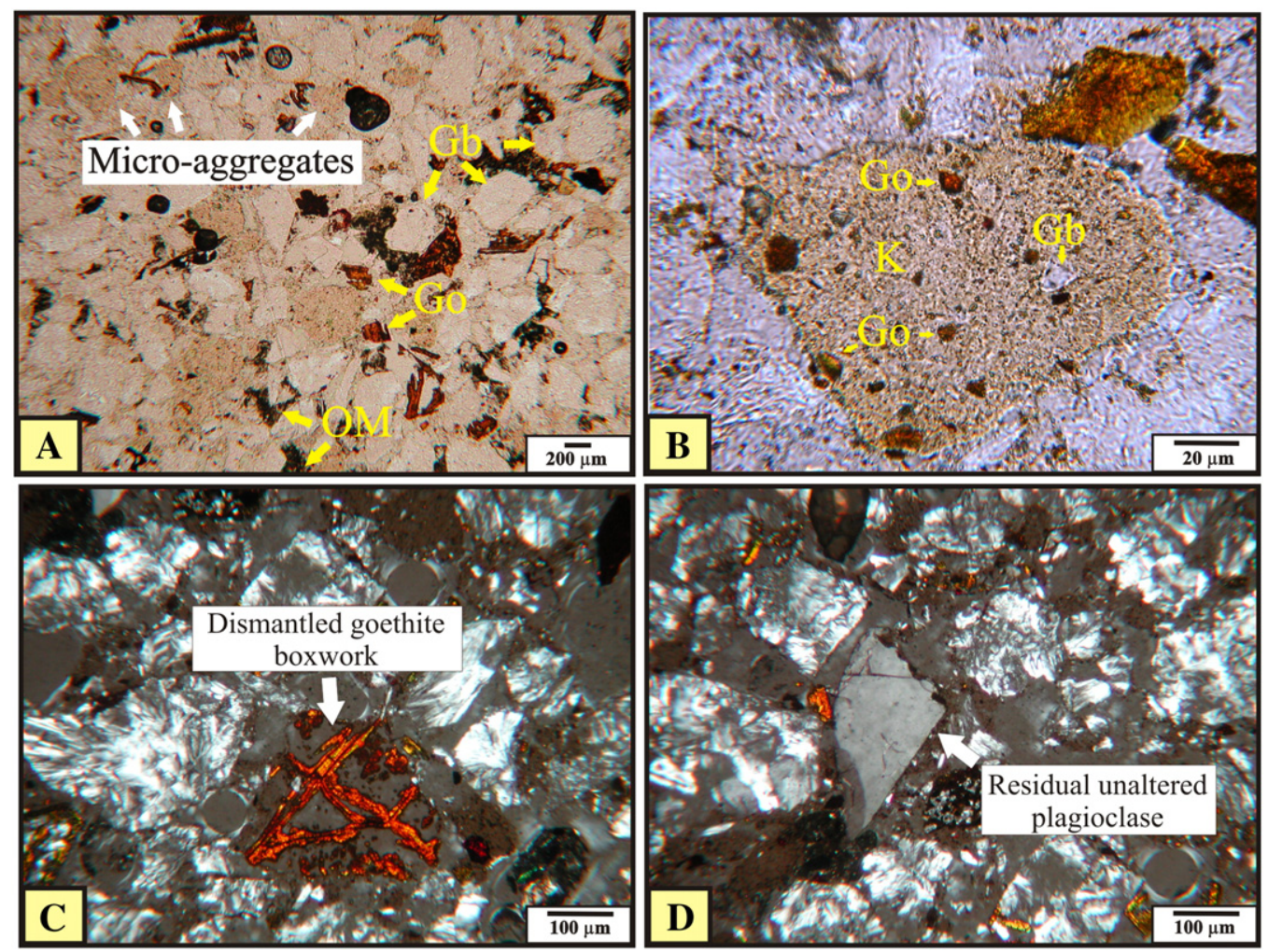

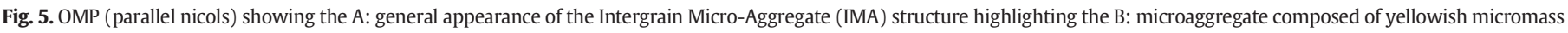

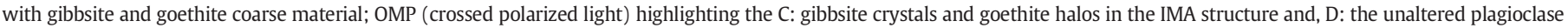
among the gibbsite crystals. $\mathrm{Gb}=$ gibbsite; $\mathrm{Go}=$ goethite; $\mathrm{K}=$ kaolinite and $\mathrm{OM}=$ organic matter.

1985). These fragments are formed mainly by gibbsite with traces of kaolinite and goethite (Fig. 8). The micromass contains gibbsite, kaolinite, goethite and anatase (Fig. 8). The minerals of the coarse material have points of contact with each other or are very close. Thus, the microstructure suggests a transition between close and single spaced porphyric (Stoops, 2003).

FIM occurs within the features with diverse shapes, especially tubular, spherical, and glaebular/amoeboidal morphologies (Fig. 9A). These features are only found on the top surface of the Morro do Buraco and Morro da Torre, and are absent in deeper layers. These microstructures have a whitish colour with very fine texture (Fig. 9A), and thin reddish lines are present, suggesting Fe migration across a redox microgradient.

FIM is mainly formed by gibbsite with a smaller amount of goethite (Fig. 8). Micromorphologically it is characterised by the presence of small gibbsite crystals whose growth direction is perpendicular to the pores located in the central portion of the features (Fig. 9B). Successive aligned crystal sequences were observed, suggesting that the gibbsite crystallised outwards from the central pore and branches (Fig. 9C). The gibbsite crystals forming the fine monic microstructure are much smaller than those in alteromorphs derived from direct plagioclase alteration, as illustrated in the backscattered electron images (Fig. 9D and $\mathrm{E})$.

\section{Discussion}

For the termite-related structures, the results indicate that the origin of the IMA is associated with the bioturbation of previous, isalteritic residual bauxite coarse blocks not transformed into clay, whereas the GRA is associated with the bioturbation of the clay itself in an admixture with relict, resistant gibbsite crystals.

In the Barro Alto bauxitic massif, boehmite was not identified in any other product of the evolution of bauxite except in samples associated with termite bioturbation (Oliveira et al., 2009, 2013a, 2013b). This evidence strongly indicates that termites have a marked role in the mineralogical transformation of the bauxite studied, i.e., via the transformation of gibbsite to boehmite.

Boehmite is a monohydrate aluminium oxy-hydroxide $(\alpha-\mathrm{AlOOH})$. According to Trolard and Tardy (1987, 1989), Trolard (1988) and Tardy et al. (1990), the stability field of boehmite, as in kaolinite, Algoethite, Al-hematite, and gibbsite, is a function of the particle size, medium temperature, and thermodynamic activity of water $\left(a_{w}\right)$. In the specific case of boehmite, water deficient conditions are necessary for their formation, i.e., a semi-arid climate (Singh, 1982). In Brazil, the bauxites are mostly gibbsitic (Melfi, 1997), and only one occurrence of boehmite has been recognised in Brazilian bauxite, specifically in the Lages region, Santa Catarina State, Brazil (Formoso et al., 1997), where a boehmite derived from alkaline rocks (phonolites) has been identified. Aquino (2007) confirmed this finding and attributed its genesis to the dehydration of gibbsite.

Experiments have shown that this transformation can occur in two ways (Gong et al., 2002): I - the dehydration of gibbsite and boehmite formation by in situ nucleation (transformation) or II - the dissolution of gibbsite and boehmite formation by nucleation from the solution (neoformation). In the first case, the transformation of gibbsite to boehmite by dehydration can be induced by reducing the thermodynamic activity of water $\left(\mathrm{a}_{\mathrm{w}}\right)$ at a constant temperature, increasing the temperature with a constant $a_{w}$, or by reducing the $a_{w}$ and increasing the temperature simultaneously (Tardy et al., 1990). This behaviour explains why gibbsite-boehmite paragenesis is stable in the absence of $\mathrm{H}_{2} \mathrm{O}$ as an independent phase, allowing for boehmite to be found mainly in the upper parts of the profiles, where increased temperature resulting from the direct incidence of solar radiation induces less stable moisture conditions (Chesworth, 1972). Boulangé (1984) observed that the oscillation of the water table that periodically desiccates the gibbsite cuirasse was responsible for the transformation of gibbsite to boehmite from Ivory Coast bauxite. 


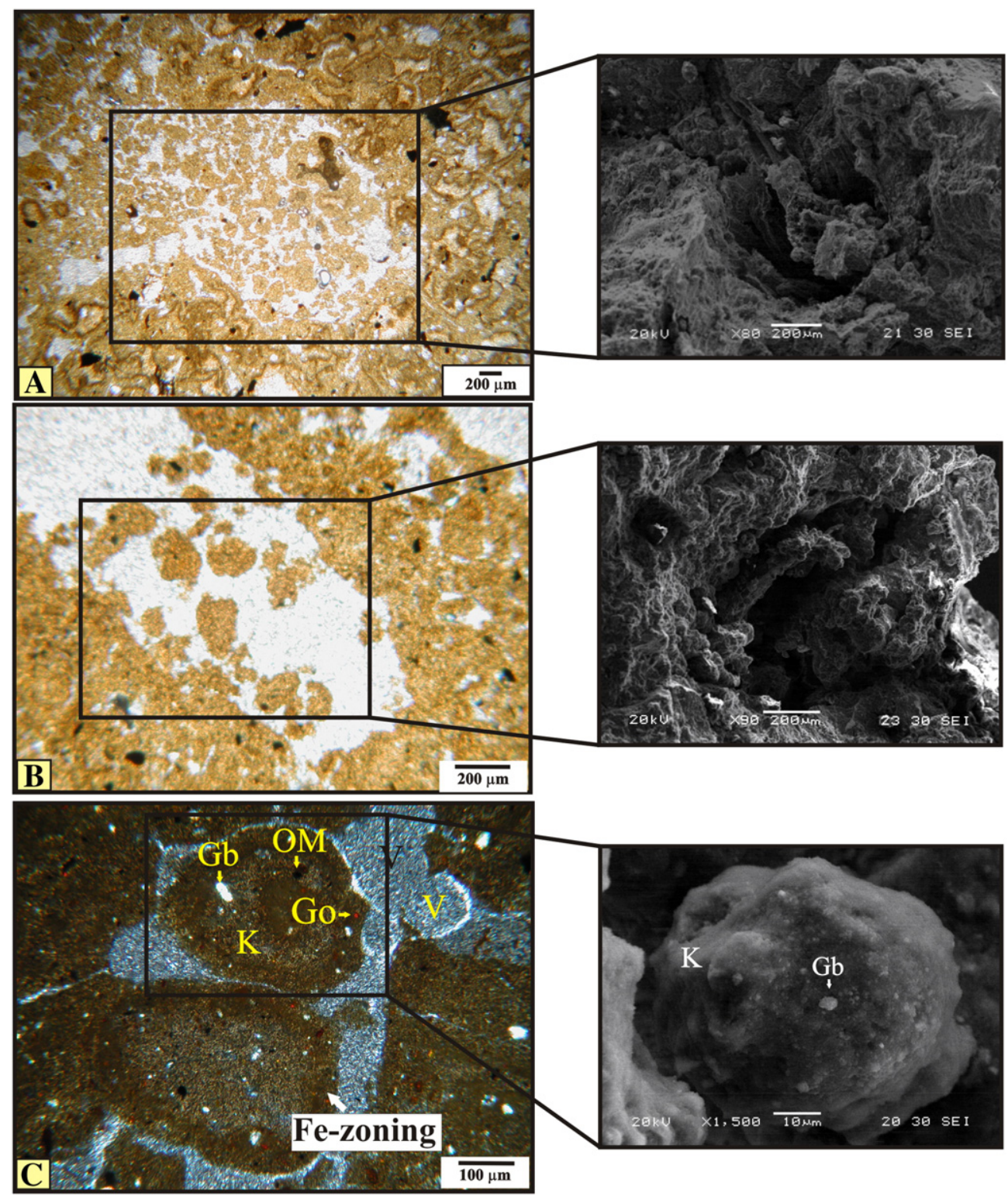

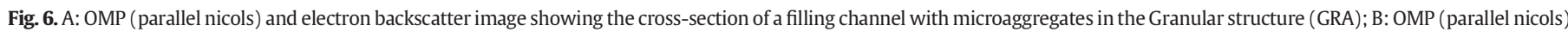

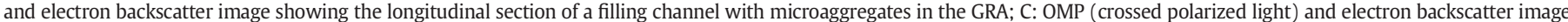
showing microaggregates in the GRA within iron zoning, gibbsite and goethite as crystals inside. $\mathrm{Gb}=$ gibbsite; Go $=$ goethite; $\mathrm{K}=$ kaolinite; $\mathrm{V}=$ void and $\mathrm{OM}=$ organic matter.

If the origin of boehmite in Barro Alto had been solely related to the dehydration of gibbsite in the upper sections of the profiles, it would also be identified in other profiles where bioturbation was not observed. However, it did not occur. The boehmite in microstructure produced by termites is restricted to the clay matrix, including the channel infilling surrounded by clay with gibbsite crystals at a depth of $6 \mathrm{~m}$. This clearly suggests that the transformation of gibbsite to boehmite in Barro Alto is directly linked to termite activity by the ingestion and passage of gibbsite through the digestive tract of termites, hence characterising a mineralogical neoformation.

With respect to root activity, the genesis of the PFR is related to the in situ fragmentation of former massive bauxite bodies. This fragmentation occurs through root growth and is facilitated by the existence of fractures in bauxite itself, thereby allowing for deeper root and water penetration (Eggleton and Taylor, 2008; Hao et al., 2010; Laskou and Economou-Eliopoulos, 2007; Nahon, 1991; Schwars, 1996; Tardy, 1993; Thomas, 1994). Initially, cavities and holes are formed, which are progressively fragmented until they finally constitute the bauxite fragments. These fragments are geochemically degraded and will become rounded, to constitute typical nodules (Bullock et al., 1985), until they are completely digested by pedogenetic processes and transformed into soils. The geochemical conditions promoted by cycling silica surface by vegetation, favour kaolinite neoformation in micromass (Lucas et al., 1993).

The genesis of FIN, in turn, is related to the crystallisation of gibbsite surrounding the cavities left by either decayed roots or termite galleries. Aluminium complexed by organic matter in solution formed in the upper parts of the profiles by gibbsite dissolution in a low-pH environment caused by the release of organic acids by root activity and decompositions. These solutions percolated through the profiles reaching lower depths, where gibbsite was recrystallised as cavity infillings.

\section{Conclusions}

The role of cumulative biological activity in the evolution of aluminous lateritic areas can occur via different pathways that cause the 

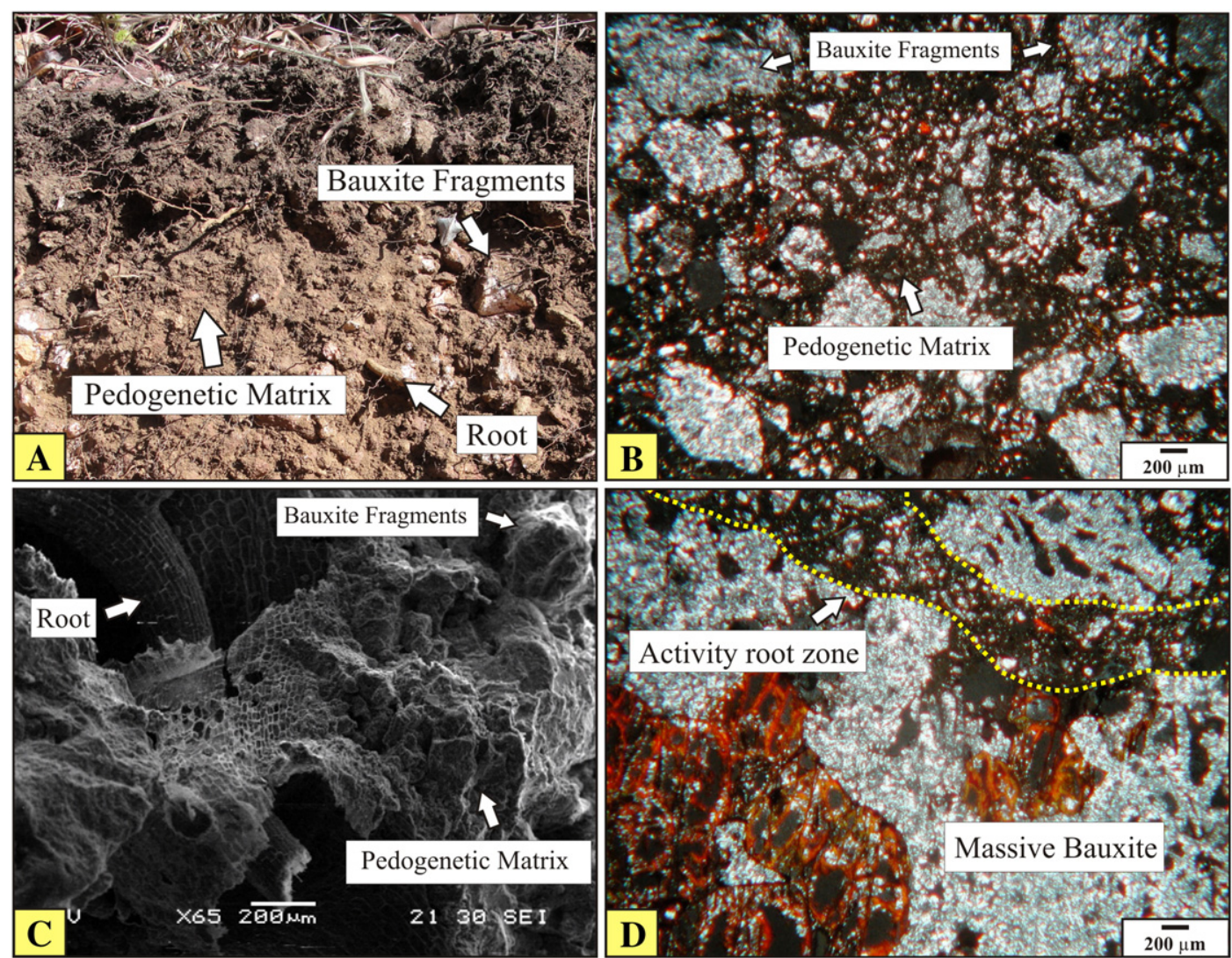

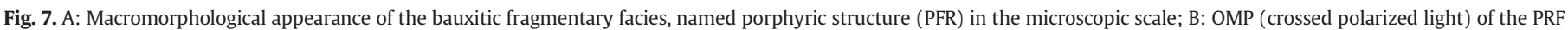

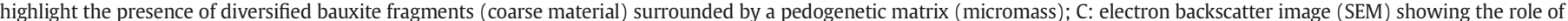
roots in forming the PRF; D: OMP (crossed polarized light) highlighting the root activity fragmenting the massive bauxite, forming the activity root zone.

microstructural and mineralogical transformations. In Barro Alto, the following transformations were identified side by side: I - bioturbation caused by termites and II - mechanical and geochemical degradation promoted by roots.

In the bioturbation process promoted by termites, two types of structures were formed: I - an intergrain micro-aggregate characterised by gibbsite crystals derived from the bioturbation of isalteritic bauxite blocks and boulders located at the bottom of the profile and II - a granular structure characterised by a clay matrix consisting of termitic microaggregates with gibbsite fragments immersed in a kaoliniticgibbsitic-goethitic-bohemitic micromass. This bioturbated micromass was formed by the clay derived by the geochemical degradation of isalteritic bauxite.

The bohemite phase is only found in structural associated with termite activity.

The processes associated with the mechanical degradation and geochemical transformations caused by roots were responsible for the genesis of two types of structures: I - a porphyric with bauxite fragments

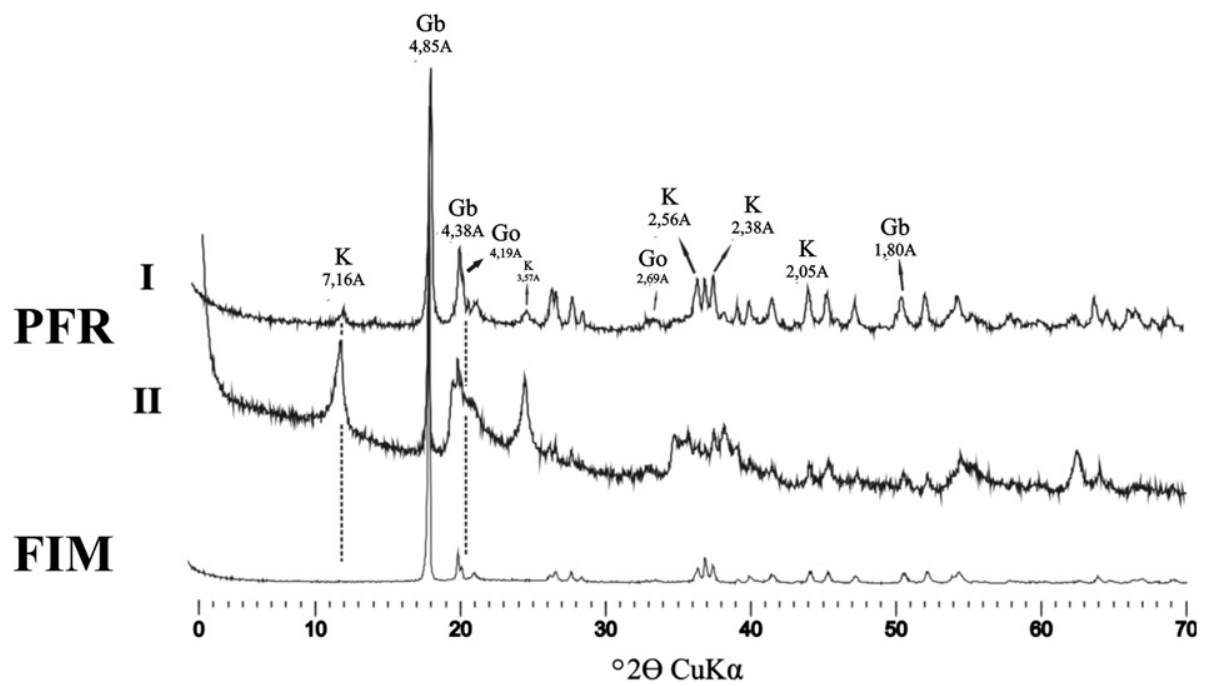

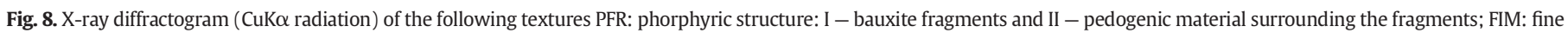
monic structure. $\mathrm{Gb}=$ gibbsite; $\mathrm{Bo}=$ boehmite; $\mathrm{Go}=$ goethite; $\mathrm{K}=$ kaolinite. 

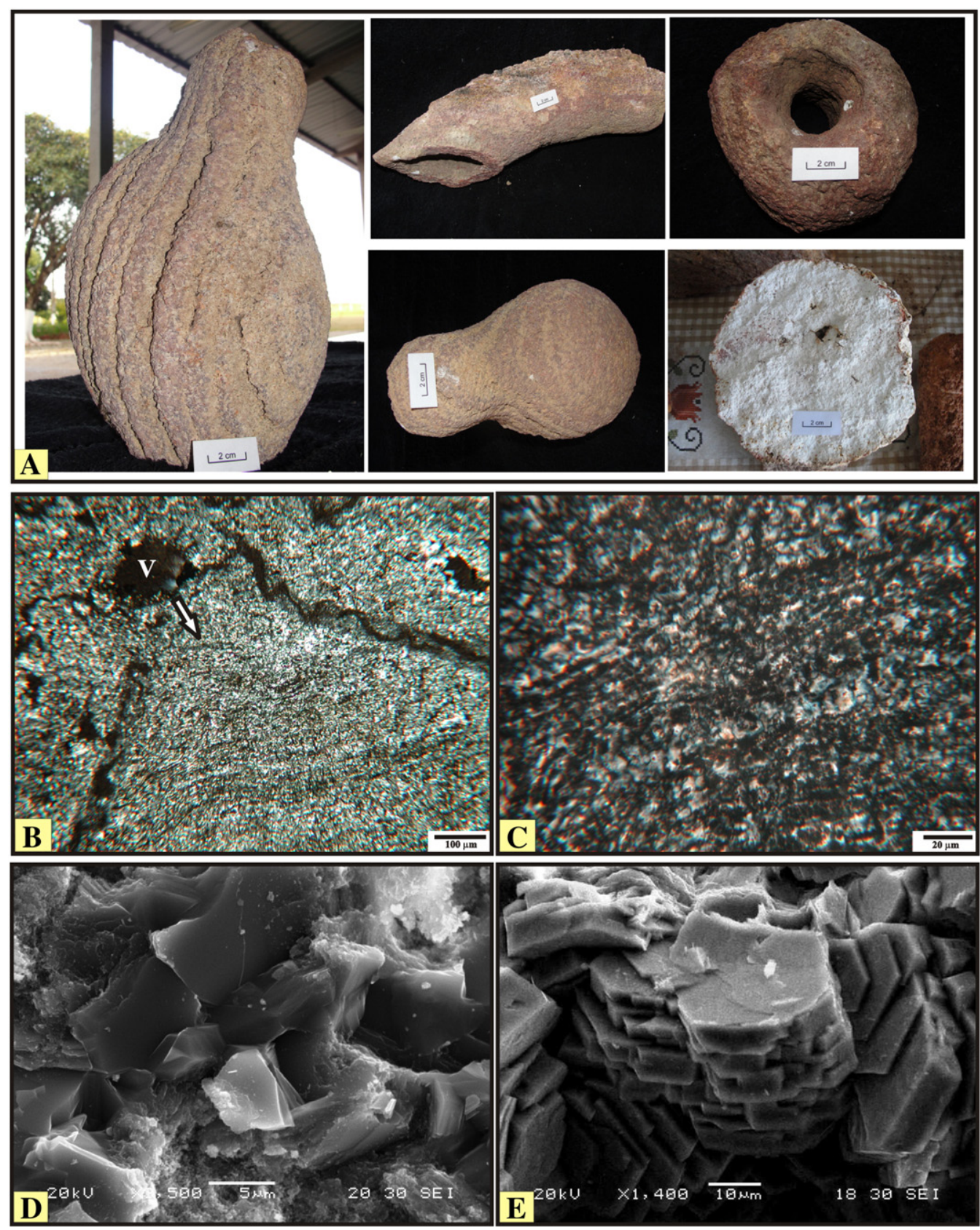

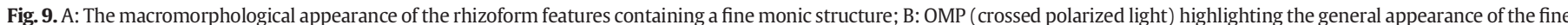

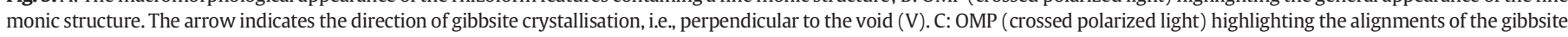

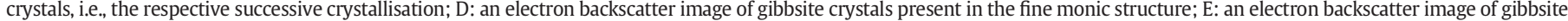
crystals formed directly from plagioclase alteration (Oliveira et al., 2011).

surrounded by a pedogenetic matrix and II - fine monic structure, whose gibbsite neoformation was constrained or framed by existing formed by roots or galleries promoted by termite activity.

\section{Acknowledgements}

The authors thank CNPq (Conselho Nacional de Desenvolvimento Científico e Tecnológico) and CAPES (Coordenação de Aperfeiçoamento de Pessoal de Nível Superior) for financial support. We are grateful to EDEM (Empresa de Desenvolvimento em Mineração e Participações Ltda) for financial support and field assistance and providing analysis and samples.

\section{References}

Almeida, F.F.M., Hasui, Y., Brito Neves, B.B., Fuck, R.A., 1981. Brazilian structural provinces: an introduction. Earth Sci. Rev. 17, 1-29.

Aquino, T.F., 2007. Beneficiamento químico da bauxita de Santa Catarina. Dissertação (Mestrado em Engenharia Química) Dep. de Engenharia, Universidade Federal de Santa Catarina, Florianópolis (103 pp.).

Beauvais, A., 2009. Ferricrete biochemical degradation on the rainforest savannas boundary of Central African Republic. Geoderma 150, 379-388.

Benyarku, C.A., Stoops, G., 2005. Guidelines for Preparation of Rock and Soil Thin Sections and Polished Sections. Quadern DMACS 33. Department of Environment and Soil Science, University of Lleida, Lleida, Spain.

Black, H.I.J., Okwakol, M.J.N., 1997. Agricultural intensification, soil biodiversity and agroecosystem function in the tropics: the role of termites. Appl. Soil Ecol. 6 37-54. 
Boulangé, B., 1984. Les formations bauxitiques latkntiques de Côte d'Ivoire. Les facies, leu transformation, leur distribution et l'évolution du modelt. Trav. Doc. ORSTOM 175 (341 pp.).

Branner, J.C., 1896. Decomposition of rocks in Brazil. Geological Society of America Bulletin 7, 255-314.

Brasil, Ministério das Minas e Energia, Departamento Nacional da Produção de Minerais, Projeto RADAMBRASIL, 1981, 1981. Folhas SC.22 e SD.22: geologia, geomorfologia, pedologia, vegetação e uso potencial da terra. Rio de Janeiro, v.22 e 25 (524pp.).

Brewer, R., Sleeman, J.R., 1988. Soil Structure and Fabric. CSIRO, Australia (173 pp.)

Brindley, G.W., Brown, G., 1980. Crystal structures of clay minerals and their X-ray identification (monograph 5). Min. Soc. (London, 495 pp.).

Bullock, P., Fedoroff, N., Jongerius, A., Stoops, G., Tursina, T., Babel, U., 1985. Handbook for Soil Thin Section Description. Waine Research Publications, Wolverhampton (152 pp.).

Cancello, E., 1989. Revisão de Cornitermes wassman (Isoptera, Termitidae, Nasutitermi tinae). (Ph.D. Thesis) Universidade de São Paulo, São Paulo, Brazil.

Chesworth, W., 1972. The stability of gibbsite and boehmite at the surface of the earth Clay Clay Miner. 20, 369-374.

Dangerfield, J.M., McCarthy, T.S., Ellery, W.N., 1998. The mound-building termite Macrotermes michaelseni as an ecosystem engineer. J. Trop. Ecol. 14, 507-520.

Darwin, C., 1881. The Formation of Vegetable Mould Through the Action of Worms with Some Observations on Their Habits. John Murray, London (298 pp.).

Delvigne, J.E., 1998. Atlas of Micromorphology of Mineral Alteration and Weathering, 3rd ed. Canadian Mineralogist Special Publication (509 pp.).

DeSouza, O., Araujo, A., Reis Jr., R., 2009. Tropic controls delaying foraging by termites: reasons for the ground being brown? Bull. Entomol. Res. 99, 603-609.

Dokuchaev, V.V., 1883. The Russian Chernozem Report to the Free Economic Society (in Russian). Imperial Univ. of St, Petersburg, St. Petersburg, Russia.

Eggleton, R.A., Taylor, G., 2008. Effects of some macrobiota on the Weipa Bauxite, northern Australia. Aust. J. Earth Sci. 55, 71-82.

Eschenbrenner, V., 1986. Contribution des termites a la microaggregation des sols tropicaux. Cah. Orstom, Ser. Pedol. 22, 397-408.

Espindola, C.R., 2008. In: Unicamp (Ed.), Retrospectiva crítica sobre a Pedologia (Campinas, 397 pp.).

Formoso, M.L.L., Dani, N., Valeton, I., 1997. The bauxite of Lages District, In: Carvalho, A., Boulangé, B., Melfi, A.J., Lucas, Y. (Eds.), Brazilian Bauxites, 1rd ed. USP/FAPESP/ ORSTOM, São Paulo, pp. 273-308.

Fregonezi, G.A.F., Brossard, M., Guimarães, M.S., Medina, C.C., 2001. Modificações morfológicas e físicas de um latossolo argiloso sob pastagem. R. Bras. Ci. Solo 25, 1017-1027.

Garnier-Sillan, E., Villemin, G., Toutain, F., Renoux, J., 1985. Formation de micro-agrégats oragno-minéraux dans lês feces de termites. C. R. Acad. Sci. 301, 213-218.

Gong, X.Y., Qian, M.X., Liu, J., Pederson, L.A., Hobbs, D.T., McDuffie, N.G., 2002. Gibbsite to boehmite transformation in strongly caustic and nitrate environments. Ind. Eng. Chem. Res. 42 (10), 2163-2170.

Hao, X., Kwunlun, L., Wang, R., Sun, W., Li, Y., 2010. The geomicrobiology of bauxite deposits. Geosci. Front. 1, 81-89.

Harris, R.F., Chesters, G., Allen, O.N., 1966. Dynamics of soil aggregation. Adv. Agron. 18 107-169.

Holt J.A. Coventry, R. Sinclair, D.F. 1998. Some aspects of the biology and pedologica significance of mound-building termites in a red and yellow earth landscape near charters towers, north Queensland. Aust. J. Soil Res. 18, 97-109.

ISSS Working Group, 2006. World Reference Base for Soil Resources. International Society of Soil Sciences (ISSS). International Soil Reference and Information Centre (ISRIC) and 73 Food and Agriculture Organization of the United Nations (FAO). World Soil Report. FAO, Rome.

Jungerius, P.D., Van den Ancker, J.A.M., Mücher, H.J., 1999. The contribution of termites to the microgranular structure of soils on the Uasin Gishu Plateau, Kenya. Catena 34 349-363.

Kooyman, C., Onk, R.F.M., 1987. Distribution of termite (Isoptera) species in southwestern Kenya in relation to land use and the morphology of their galleries. Biol. Fertil. Soils 3 , 69-73.

Lal, R., 1988. Effects of macrofauna on soil properties in tropical systems. Agric. Ecosyst. Environ. 24, 101-116.

Laskou, M., Economou-Eliopoulos, M., 2007. The role of micro-organisms on the mineralogical and geochemical characteristics of the Parnassos-Ghiona bauxite deposits, Greece. J. Geochem. Explor. 93, 67-77.

Lavelle, P., Pashanasi, B., 1989. Soil macrofauna and land management in Peruvian Amazonia (Yurimaguas, Loreto). Pedobiologia 33, 283-291.
Lavelle, P., Blanchardt, E., Martin, A., Spain, A.V., Martin, S., 1992. Impact os soil fauna of the properties of soil in humid tropics. Soil Sci. Soc. Am. 29, 157-185.

Lee, K.E., Foster, R.C., 1991. Soil fauna and soil structure. Aust. J. Soil Res. 29, 745-775.

Lee, K.E., Wood, T.G., 1971. Termites and Soils. Academic Press, London (251 pp.).

Leonard, J., Rajot, J.L., 2001. Influence of termites on runoff and infiltration: quantification and analysis. Geoderma 104, 17-40.

Lucas, Y., Luizão, F.J., Chauvel, A., Rouiller, J., Nahon, D., 1993. The relation between biological activity of the rainforest and mineral composition of the soils. Science 260, 521-523.

Mando, A., Stroosnijder, L., 1999. The biological and physical role of mulch in the rehabilitation of crusted soil in the Sahel. Soil Use Manag. 15, 123-130.

Martin, J.P., 1945. Microorganisms and soil aggregation I: origin and nature of some of the aggregates substances. Soil Sci. 61, 163-164.

Martin, J.P., 1946. Microorganisms and soil aggregation II: influence of the bacterial polysaccharides on soil structure. Soil Sci. 60, 157-166.

Melfi, A.J., 1997. Brazilian bauxite deposits: a review, In: Carvalho, A., Boulangé, B., Melfi, A.J., Lucas, Y. (Eds.), Brazilian Bauxites, 1rd ed. USP/FAPESP/ORSTOM, São Paulo, pp. 3-22.

Miklós, A.A.W., 1995. Biodynamique d'une couverture pédologique dans da region de Botucatu (Brésil-SP). (Ph.D. Thesis) Université de Paris, Paris, France.

Nahon, D.B., 1991. Introduction to the Petrology of Soils and Chemical Weathering. John Wiley and Sons, New York (313 pp.).

Oliveira, F.S., Varajão, A.F.D.C., Varajão, C.A.C., Boulangé, B., Costa, J.L.G., Vessani, L.A., 2009. Alteração supergênica e morfogênese tropical no Complexo Máfico-Ultramáfico Acamadado de Barro Alto, GO. Geoderma 28, 255-272.

Oliveira, F.S., Varajão, A.F.D.C., Varajão, C.A.C., Boulangé, B., Gomes, N.S., 2011. Bauxitization of anorthosites from Central Brazil. Geoderma 167-168, 319-327.

Oliveira, F.S., Varajão, A.F.D.C., Varajão, C.A.C., Boulangé, B., Soares, C.C.V., 2013a. Mineralogical, micromorphological and geochemical evolution of the facies from the Bauxite deposit of Barro Alto, Central Brazil. Catena 105, 29-39.

Oliveira, F.S., Varajão, A.F.D.C., Varajão, C.A.C., Boulangé, B., 2013b. A comparison of properties of clay minerals in isalteritic and in degraded facies. Clay Miner. 48, 697-711.

Reatto, A., Bruand, A., Silva, E.M., Guégan, R., Cousin, I., Brossard, M., Martins, E.S., 2009. Shrinkage of microaggregates in Brazilian Latosols during drying: significance of the clay content, mineralogy and hydric stress history. Eur. J. Soil Sci. 60 (6), 1106-1116.

Sarcinelli, T.S., Schaefer, C.E.G.R., Lynch, L.S., Arato, H.D. Viana, J.H.M. Albuquerque Filho, M.R., Gonçalves, T.T., 2009. Chemical, physical and micromorphological properties of termite mounds and adjacent soils along a toposequence in Zona da Mata, Minas Gerais State, Brazil. Catena 76, 107-113.

Schaefer, C.E.G.R., 2001. Brazilian latosols and their B horizon microstructure as long-term biotic constructs. Aust. J. Soil Res. 39, 909-926

Schwars, T., 1996. Distribution and genesis of bauxite on the Mambilla Plateau, Nigeria. Appl. Geochem. 12, 119-131.

Singh, S.S., 1982. The formation and coexistence of gibbsite, boehmite, alumina and alunite at room temperature. Can. J. Soil Sci. 62, 327-332.

Stoops, G., 2003. Guidelines for Analysis and Description of Soil and Regolith Thin 268 Sections. Soil Science Society of America Inc., Madison, Wisconsin.

Tardy, Y., 1993. Pétrologie des latérites et des sols tropicaux. Masson, Paris (535 pp.)

Tardy, Y., Trolard, F., Roquin, C., Novikoff, A., 1990. Distribution of hydrated and dehydrated minerals in lateritic profiles and landscapes. Geochemistry of the Earth's Surface and of Mineral Formation. Second International Symposium, France, Proceedings, pp. 133-136.

Taylor, H.M., Brar, G.S., 1991. Effect of soil compaction on root development. Soil Tillage Res. 19, 111-119.

Thomas, M., 1994. Tropical Geomorphology: a Study of Weathering on Landform Development in Warm Climate. John Wiley \& Sons, New York (313 pp.).

Tisdal, J.M., Oades, J.M., 1982. Organic matter and water-stable aggregate in soils. J. Soil Sci. 33, 141-163.

Trolard, F., 1988. Physicochimie des cuirasses latéritiques. Domaines de stabilite des oxydes et hydroxydes de fer et d'aluminium (Thèse Univ. Louis Pasteur, Strasbourg. 213 pp.).

Trolard, F., Tardy, Y., 1987. The stabilities of gibbsite, boehmite, aluminous goethites and aluminous hematites in bauxites, ferricretes and laterites as function of water activity, temperature and particle size. Geochim. Acta 51, 945-957.

Trolard, F., Tardy, Y., 1989. A model of $\mathrm{Fe}^{3+}$-kaolinite, $\mathrm{A}^{3+}{ }^{+}$-goethite $2 \mathrm{~A} 1^{3+}$-hematite equilibria in laterites. Clay Miner. 24, 1-21.

Ugolini, F.C., Edmonds, R.L., 1983. Soil biology. 1. Concepts and interactions. In: Wilding L.P., Smeck, N.E., Hall, G.F. (Eds.), Soil Taxonomy and Pedogenesis. Elsevier Sci. Publ, Amsterdam, pp. 193-231. 